\title{
Authentic Design of Online Mathematics Assessment on Senior High Math Course
}

\author{
Buchori A*, Setyawati RD, Endahwuri D, Kartono and Masrukan \\ Faculty of Mathematics and Science Education, Semarang PGRI University and Semarang State University, Kota Semarang, Indonesia
}

"Corresponding author: Buchori A, Faculty of Mathematics and Science Education, Semarang PGRI University and Semarang State University, Kota Semarang, Indonesia, Tel: +62248316377; E-mail: buccherypgri@gmail.com

Received date: August 16, 2016; Accepted date: August 25, 2016; Published date: August 31, 2016

Copyright: ( 2016 Buchori A, et al. This is an open-access article distributed under the terms of the Creative Commons Attribution License, which permits unrestricted use, distribution, and reproduction in any medium, provided the original author and source are credited.

\begin{abstract}
Rapid technological developments of this decade requires lecturers to pack an interesting learning for students with ICT based, one concrete manifestation of creativity by lecturer is made the form of online math assessment. From the results of the survey in the Kopert is VI Central Java region, there are still some colleges still use conventional ratings in high school math courses. The main reason is the high school math courses is a subject which is very important for students to be understood in theory and practice in preparation to become teachers in secondary schools.
\end{abstract}

The purpose of this study is to produce products such as online math assessment for high school math courses that is valid or feasible to be used in all of mathematics education program in Central Java, which can produce human resources that is intelligent, creative, innovative and able to compete in the 21st century. Research method used in this study is Borg and Gall development model that is in practice only to the stage of Develop preliminary form of product Phase to produce valid product by experts. This stage is expert validation by four lecturers namely two lecturers of subject matter experts and two media expert lecturers from University PGRI of Semarang and Semarang State University.

From the research results, it can be concluded that the online math authentic assessment with wondershareBased has been valid or feasible, validated by experts, namely: (1) validation of the first subject matter expert with the percentage of the general aspects of $87.5 \%$, the aspect of the material substance of $91.7 \%$, and feasibility aspects of language by $94.4 \%$ (2) validation of the second subject matter experts at $88 \%$, the aspect of the material substance of $92 \%$, and feasibility aspects of the language of $88.9 \%$ (3) validation of media with the percentage of the general aspects of $88 \%$, presenting aspects of learning as much as $85 \%$, the feasibility aspects of language by $75 \%$, and feasibility aspects of the graph $82.14 \%$ (4) validation of media with the percentage of the general aspects of $81.25 \%$, presenting aspects of learning as much as $75 \%$, the feasibility aspects of language by $81.25 \%$, and feasibility aspects of the graph $75 \%$. Of the results percentage of the expert validation, the resulting product is feasible or valid. The validity of these products are expected to facilitate lecturers and students in learning in implementing the learning and assessment process, then conducted a limited test on the assessment authentic product and it is obtained an average of student learning outcomes is more than 85 . This shows that the website media makes the assessment and mastery of the material process easier.

Keywords: Design; Online mathematics assessment authentic; Wondershare; Humanity

\section{Introduction}

The increasingly rapid development of technological world makes a lot of conveniences that can be felt by all of humanity; technology helps people in different fields, one of which is the field of education. It is undeniable that learning is now very dependent on the development of the technology itself because technology is found to help all human work.

Math is one of subjects that are closely related to the technology. Mathematics learning should be linked with technology and its application in life so that students can view mathematics as a meaningful science. In the rapid development of the world, it is required to lecturers to be able to produce student who is qualified in the global challenge, in accordance with the Semarang PGRI University's Strategic Plan therein stipulated that the lecturers should be able to create exciting learning with ICT-based, therefore, it is required for lecturers to create IT-based research that is technology to teaching and learning mathematics. In this design study, technology applications in mathematics materials assessment will be presented in the form of e-assessment, so that students are able to understand and apply the holistic assessment. This is in accordance with Greenstein [1] which explains that this 21 st century required an educator who is able to authentically assess both in ICT-based or conventional.

Naufal [2] explained that there are many available software of eassessment maker, one of which is Wondershare. Wondershare Software can make math assessment both online and offline become more attractive and easy to apply. This software can be used in order to make presentation more attractive with musical effects that appear with SWF or EXE file, so that students can learn with more fun. These files can also be incorporated into TABLET, so as to appear more attractive. 
One of the subjects that are taught in mathematics education program is a high school math in which discuss about all the basic material of algebra, geometry, statistics, and others in high school. Safari [3] states that the purpose of high school mathematics learning is to develop the ability to think logically, develop spatial intuition, analyze the data, and impart knowledge to support other materials, and can read and interpret mathematical arguments. Basically, high school math has a greater opportunity to be understood by learners compared with the other branches of mathematics. This is because the ideas of high school math are already known by students from their school, for example, line, plane and space and the basics of algebra and statistics. Nevertheless, the evidence shows that the results of the high school math courses are still low. To overcome the difficulties in learning the high school math courses, one of options that can be implemented is applying authentic online assessment.

From the results of final exams year 2012/2013, it is gained 70\% of first semester students in PGRI Semarang University received grades below 60 , this is because many obstacles as follows:

- The big number of students weak in absorbing high school math material because when they learn at the high school level the material being taught limited on the formula application.

- Characteristics of high school math itself that require students to be thorough in sketching pictures, analyze the data, logic, and to prove the application of mathematical problems in everyday life.

- Very few reference books made by PGRI Semarang University lecturer that discussed the high school math assessment matter, and should seek the appropriate literature.

- The absence of books of high school math courses assessment that is made with IT based at the University PGRI of Semarang, which seem outdated.

\section{Method}

\section{Study location and time}

- Location

Location of the study is at the University PGRI of Semarang.

- Research time

The study time started at the beginning of the school year 2015-2016 for approximately 8 months.

\section{Study subject}

The population in this study is all students of fourth semester mathematics education study program of University PGRI of Semarang academic year 2014/2015.

\section{Research design}

The research design used in this study is a Borg and Gall model with 10 stages, namely, in the first year implemented Steps 1-6 are (1) the potential and problems, (2) data collection, (3) the design of the product, (4) validation of design, (5) revision of design, (6) product trial, next in the second year are implemented stage 7-10 (7) design revised (8) usage trial (9) products revision, (10) mass-production. In the first year of this study, the stage has been implemented are (1) potential and problems, (2) data collection, (3) products design, (4) design validation (Figure 1).

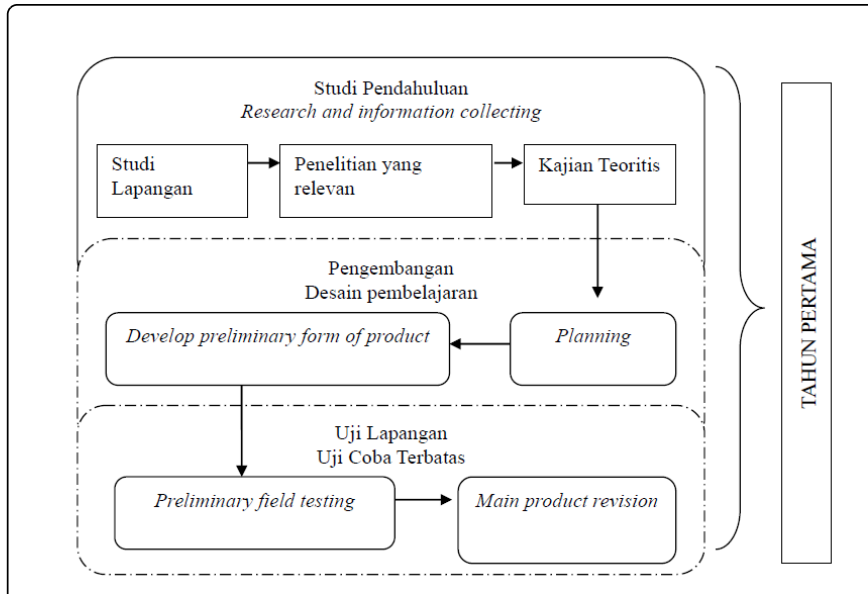

Figure 1: Stage of research and development activity.

\section{Technique of data collection}

Data collection techniques in this research are questionnaires and tests, which used questionnaires to determine the validity and used tests for products effectiveness of online math assessment authentic during the learning process takes place [4].

\section{Results and Discussion}

This development study has been adapted to the borg and gall development model which consists of 10 steps [5], based on the target of the first year of this study is a preliminary study that includes three aspects then followed by development studies which includes four aspects are described as follows:

\section{Preliminary study}

\section{Library study}

In conducting the study of literature, it has made various efforts to increase the study of theory related to the depth of material that will be made in the form of mathematics authentic assessment, books of literature used are from a variety of sources such as teachers books and students' books in the KTSP and 2013 curriculum for high school kids, high school mathematics books published by erlangga and Yudhisthira, high school math books in college, assessment books, computer books and articles on the internet that the point is to produce mathematics authentic assessment that in terms of content courses of high school math and media content is mutually integrated both online and offline [6].

\section{Field study}

In the field study, it is chosen in mathematics education program in University PGRI of Semarang, on a visit to the university gained a lot of info as follows: (1) of the lecturer and students in learning no one has used the media of mathematics authentic assessment both online and offline, (2) the absence of mathematics authentic assessment books, (3) the absence of lecturers who are able to make mathematics authentic assessment applications both online and offline. of these problems, lecturer and students in mathematics education program in University PGRI of Semarang are very enthusiastic if mathematics 
authentic assessment both online and offline that will be developed can be used at the University PGRI of Semarang and Semarang State University.

\section{Design and compilation of mathematics authentic assessment}

At the product design stage, the researchers made a draft design for developing authentic assessment in mathematics. According to Marzano [7] the steps to create the mathematics authentic assessment design are as follows (Figure 2):

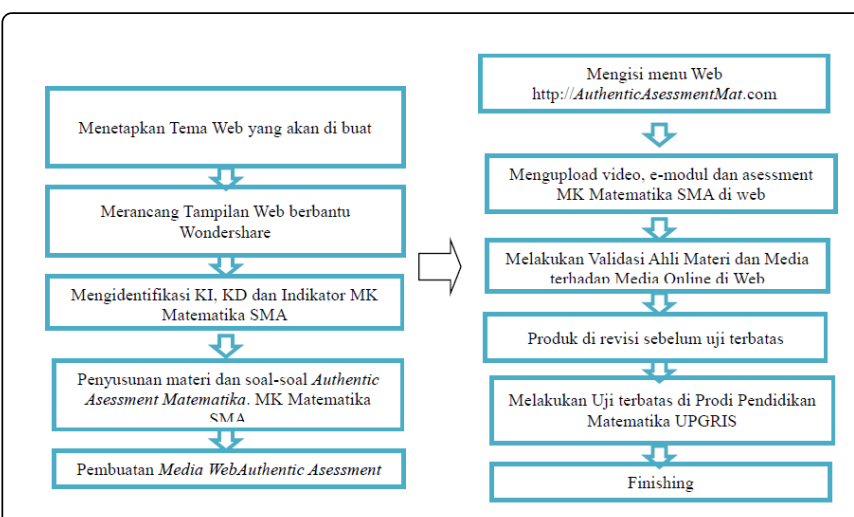

Figure 2: Steps of mathematics authentic assessment making.

\section{Development study}

\section{Design validation}

Design validation of mathematical authentic assessment in both online at http://authenticsassesmentmat.com and offline in the soft-file form on local-host address by 1) Prof. Dr. Sunandar, M.Pd. (Evaluation expert of mathematics learning of University PGRI of Semarang) and Heri Sutarto, M.Pd. (Evaluation expert of mathematics learning of UNNES) as matter validator, whereas 2) Hidalgo Murti Dewanto, M.Kom (Expert of education media at the University PGRI of Semarang) and Riza Arifudin, M.Cs (Head of mathematics learning media development center at UNNES) as Media validator with evaluation results as follows:

\section{Assessment result of product design}

Product design assessment is an activity process to assess whether the developed product in the form of mathematics authentic assessment is rationally effective or not. Previously design draft is discussed in advance with researchers team namely Achmad Buchori, M.Pd., Rina Dwi Setyowati, S.Pd., M.Pd., Prof. Dr. Kartono, M.Sc. and Dr. Masrukan, M.Sc.

Then in the validation phase, it is done by asking the opinion of the expert who is experienced to assess products design, so it can then note the advantages and disadvantages. The technique used is by using questionnaires (validation sheet). The results of the assessment as follow (Figure 3):

\section{Learning material expert}

\section{Data presentation}

From Figure 3 above, it can be seen the percentage level of achievement of learning media as follows:

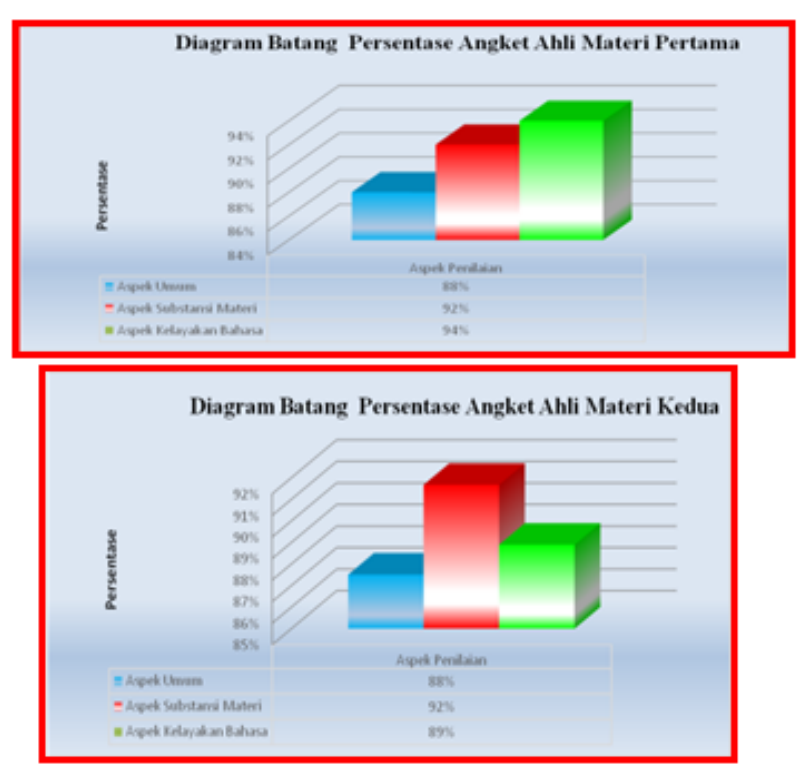

Figure 3: Assessment result of material expert for each aspect.

$$
\text { Persentase }=\frac{\sum(\text { jawaban } \times \text { bobot tiap pilihan })}{n \times \text { bobot tertinggi }} \times 100 \%
$$

From the data obtained, it is substituted into the formula (adjusted to the number of respondents) that can be calculated by the following calculation:

$$
\text { Persentase }=\frac{138}{19 \times 2 \times 4} \times 100 \%=\frac{138}{152} \times 100 \%=91 \%
$$

Of the percentage that has been obtained, it is then transformed into a sentence which is qualitative. To be able to give meaning and decision-making, it is used precision as an indicator of the success of the expert validation of learning materials. The results of the percentage of the data shows that the percentage of each indicator $80 \%$ - $100 \%$ on the criterion of "Very Good". While the view of Figure 3 shows that the percentage of eligibility for the general aspects of the material gets $87.75 \%, 91.85 \%$ for the aspect of material substance, and $91.65 \%$ for the design aspect of learning. It shows the criteria for "very good ". So that in the expert test of learning materials in the media, the percentage of each item is successful or feasible (Figure 4).

\section{Learning media expert}

\section{Data presentation}

From the data obtained, it is substituted into the formulas (adjusted to the number of respondents) that are presented in Figure 4, can be calculated by the following calculation: 
Citation: Buchori A, Setyawati RD, Endahwuri D, Kartono, Masrukan (2016) Authentic Design of Online Mathematics Assessment on Senior High Math Course. Arts Social Sci J 7: 213. doi:10.4172/2151-6200.1000213

Page 4 of 5

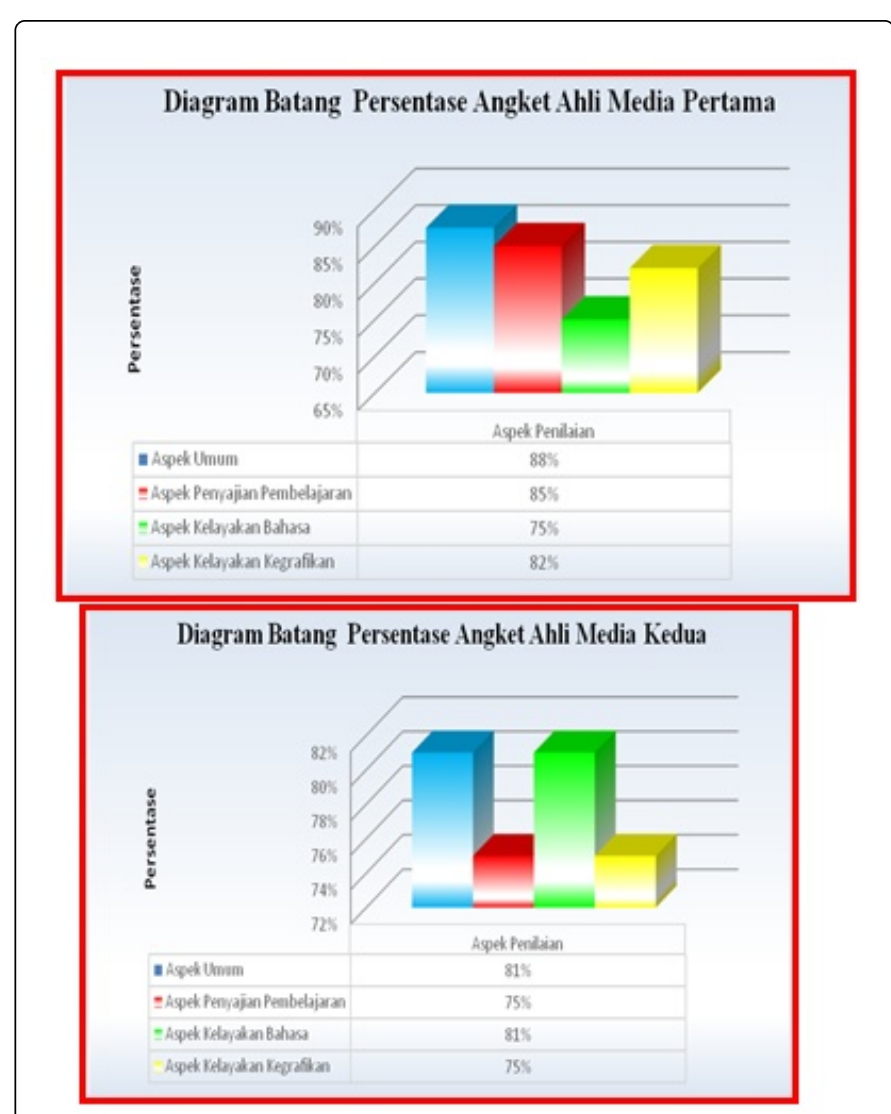

Figure 4: Assessment result of media expert for each aspect.

Persentase $=\frac{105}{20 \times 2 \times 4} \times 100 \%=\frac{128}{160} \times 100 \%=80 \%$

Of the percentage that has been obtained, it is then transformed into a sentence which is qualitative. In order to give meaning and decisionmaking, it is used accuracy as a success indicator of the expert validation of learning media. Percentages results in the table attached in annex 7 shows that the result of the analysis of each indicator is in the range of $80 \%-100 \%$, i.e., the criteria of "Very Good". While the views of Figure 4 shows that the percentage of eligibility for the general aspects of the media got $84.5 \%, 80 \%$ for software aspects, $78 \%$ for visual communication aspects and $78.5 \%$ for the learning model. It shows the criteria of "Very Good". So, that in the learning media expert test on mathematics authentic assessment, the percentage of each item is successful or feasible.

\section{Design revision}

\section{First revision of development product material}

Based on the results of the assessment or feedback of material expert, then basically mathematics authentic assessment needs to get revisions or corrections, input, open-ended questions, trying to be realized as good as possible so that the resulting development is getting better.

\section{First revision of development product media}

Based on the results of instructional media expert feedback, basically instructional media needs to get improvements, feedback, suggestions and comments; these are made by media experts in the validation sheet, trying to be realized as good as possible so that the resulting product development is better.

\section{Design improvement}

Here are four (4) suggestions that must be met after a limited test in mathematics education program at University PGRI of Semarang namely the advice of (a) media expert, (b) subject matter experts, and (c) students based on a questionnaire that they fill.

- Based on the advice of the media expert, Mr. Murti Dewanto Hidalgo, M. Kom it is obtained input that display of online Math Authentic assessment needs to include in the instructions for use of mathematics authentic assessment media look like the following (Figure 5):

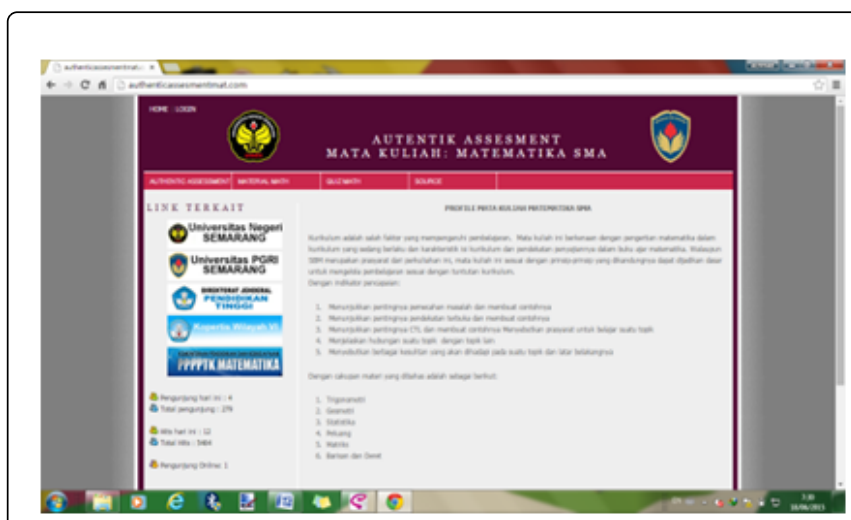

Figure 5: Previous display of math authentic assessment.

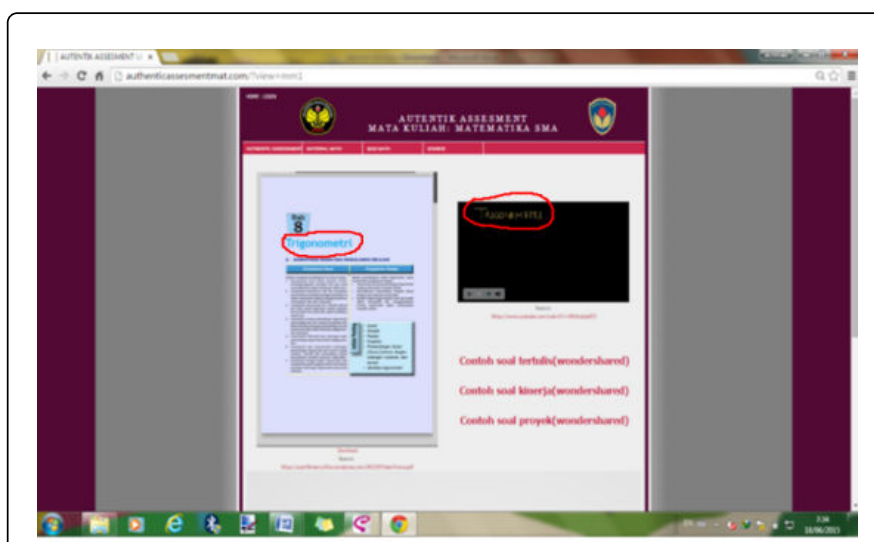

Figure 6: Display of math authentic assessment material.

- Based on advice from subject matter experts, Mr. Heri Sutarto, M.Pd it is obtained feedback that the relationship between E-book 
Citation: Buchori A, Setyawati RD, Endahwuri D, Kartono, Masrukan (2016) Authentic Design of Online Mathematics Assessment on Senior High Math Course. Arts Social Sci J 7: 213. doi:10.4172/2151-6200.1000213

Page 5 of 5

and math authentic assessment video needs to be in sync online look like the following (Figure 6):

- Based on the oral and written advice of students of mathematics education program at University PGRI of Semarang namely 31 students in mathematics education program at University PGRI of Semarang, it is obtained input as follows (Figure 7):

1. Based on interviews and a questionnaire completed by the students indicated that more than $85 \%$ of students strongly agreed if the math authentic assessment media used in the learning process in the classroom as a supplement material.

2. Students are very interested in using the online version because it is easily accessible anywhere via computer, laptop or smart-phone connected to the Internet.

3. It is expected that mathematics authentic assessment soon expanded to other subjects.

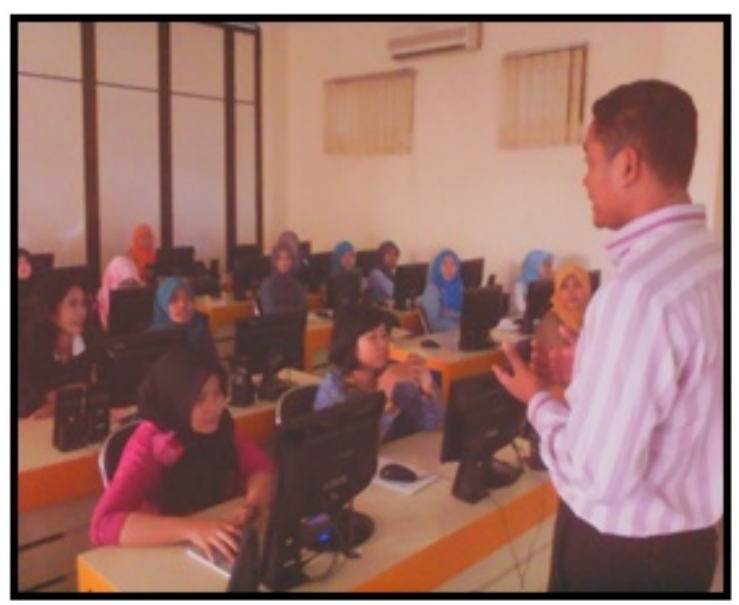

Figure 7: Lecturer guides students doing math quiz on math authentic assessment.

\section{Hypothetic product}

Hypothetic product is temporary products that are tested limitedly in mathematics education program at University PGRI of Semarang class $4 \mathrm{~B}$. The results of limited testing indicate that the hypothetical product is highly preferred by Lecturers and students of Mathematics Education Program at University PGRI of Semarang and is expected to be tested more widely.

\section{Conclusion and Suggestion}

Based on the formulation of the problem, the research data analysis and discussion of the problem, it can be summed up as follows:

\section{Conclusion}

- It had generated mathematics authentic assessment product that can be used via online and offline that is eligible to use according to subject matter experts and media experts.

- It had generated prototypes or hypothetical products of mathematics authentic assessment which will be revised in accordance with the input and advice from media experts and subject matter experts.

\section{Suggestion}

- It is expected that mathematics authentic assessment products still used by lecturer although the research team is still revising the product.

- It is expected that mathematics authentic assessment product is still used by students although the research team is still revising the product.

\section{References}

1. Laura G (2009) Assesing 21st century skills aguide to evaluating mastery and authentic learning. Corwin.

2. Naufal (2010) Interactive learning with wondershare quiz creator.

3. Safari (2003) Evaluation of the learning. Directorate general of primary and secondary education.

4. Creswell JW (2003) Research design qualitative, quantitative and mixed methods approaches. University of Nebraska, Lincoln.

5. Setyosari (2010) Methods of educational research and development. Kencana, Jakarta.

6. Zainul A (2001) Alternative assessment approach applied to teach in colleges. Ditjen Dikti Depdiknas, Jakarta.

7. Marzano (1994) Assesing student outcomes: performance asessement using the five dimensions of learning model. Alexandria association for supervision and curriculum development. 